\title{
Fertilization rate and embryo production of superovulated dairy cows after insemination with non-sorted and sex-sorted semen
}

\author{
P.L.J. Monteiro Jr ${ }^{1,5}$, A.M. Batista ${ }^{2}$, F.C. Almeida ${ }^{2}$, A.E.S. Figueirêdo ${ }^{3}$, P.C. Soares ${ }^{2}$, \\ G.F. Carneiro ${ }^{4}$, M.M.P. Guerra ${ }^{2}$ \\ ${ }^{1}$ Department of Animal Science, University of São Paulo, Piracicaba, SP, Brazil. \\ ${ }^{2}$ Department of Veterinary Medicine, University Federal Rural of Pernambuco, PE, Brazil. \\ ${ }^{3}$ Department of Veterinary Medicine, University Federal Rural of Rio de Janeiro, Seropédica, RJ, Brazil. \\ ${ }^{4} \mathrm{UAG} /$ University Federal Rural of Pernambuco, Garanhuns, PE, Brazil.
}

\begin{abstract}
The aim of this study was to evaluate the fertilization rate of cows that were superovulated and artificially inseminated with sex-sorted semen. Cows were treated with an intravaginal progesterone device plus estradiol benzoate (day 0 ). Superstimulation treatments began four days after with eight applications of FSH at $12 \mathrm{~h}$ intervals. D-Cloprostenol was administered on day 6. Progesterone device was removed on day 7, and LH was administered on day 8 . The treatments were divided as follows: NonSx, two AI with non-sorted semen were conducted 12 and $24 \mathrm{~h}$ after LH; Sx12\&24, two AI with sex-sorted semen were conducted 12 and $24 \mathrm{~h}$ after LH; and Sx24\&36, two AI with sex-sorted semen were conducted 24 and $36 \mathrm{~h}$ after LH. Embryos were recovered on day 16 and were evaluated and classified. Percentage of fertilized embryos tended to be greater for the non-sorted semen than the sex-sorted semen. The number of unfertilized oocytes was smaller when the non-sorted semen was used relative to the sex-sorted semen. There was no difference between the treatments that used sexed semen. In conclusion, the use of sex-sorted semen in superovulated dairy cows results in greater numbers of unfertilized oocytes than non-sorted. However, when only sorted semen is used AI should be performed 24 and $36 \mathrm{~h}$ after $\mathrm{LH}$.
\end{abstract}

Keyword: Brown swiss, sexed, sexing, superovulation.

\section{Introduction}

Sperm that is separated according to the sex chromosomes (X or $\mathrm{Y}$ ) can prevent sex-linked genetic diseases, save endangered animals and increase productive efficiency (Seidel and Johnson, 1999). In cattle, females are essential for calf and dairy production, while males are important for beef production. Thus, sex-sorted semen is of great interest due to its handling and economic advantages (Hamano, 2007).

Despite considerable advances in the sexsorted semen process, the fertilization rates are not the same as those obtained from non-sorted semen (Garner, 2006; Seidel and Schenk, 2008; Karakaya et al., 2014). Several studies have reported the use of different strategies for increasing the results of artificial insemination (AI) using sex-sorted semen in superovulated donors. These strategies include using different sperm concentrations (Sartori et al., 2004; Schenk et al., 2006), using fresh sex-sorted semen (Hayakawa et al., 2009), using a higher number of AIs (Peippo et al., 2009; Larson et al., 2010) and using AI at different times (Soares et al., 2011). The use of sexsorted semen in superovulated cattle is promising when considering the limitations of in vitro embryo production related to cryopreservation (Viana and Camargo, 2007).

The use of timed AI (TAI) requires hormonal treatments that ensure adequate control of follicular development and luteolysis for ovulation synchronization. These aspects have been controlled in superovulation (SOV) protocols in which the use of GnRH or LH for ovulation induction has been widely used (Nogueira et al., 2002; Chesta et al., 2005; Bo and Mapletoft, 2014), reducing the interval between the first and last ovulations (Chesta et al., 2005). Seventy-five percent of the ovulation in superovulated Bos taurus cows occurred between 24 and $36 \mathrm{~h}$ after administration of $25 \mathrm{mg}$ of LH (Martins, 2007).

Therefore, the aim of this study was to evaluate the fertilization rate and embryo production in superovulated Bos taurus cows that were inseminated in fixed time with sex-sorted and non-sorted semen. The hypothesis of this study was that TAI in superovulated cows should be performed as close as possible to the time at which a greater number of ovulation occurs to increase the fertilization rate with sex-sorted semen.

\section{Materials and Methods}

The Animal Research Ethics Committee of the Federal Rural University of Pernambuco approved all of the procedures involving animals in this study.

\section{Location and animals}

This study was conducted on a dairy farm in Pernambuco State in Northeast Brazil from January to October 2010. During this experiment, the average temperature was $22.2^{\circ} \mathrm{C}$, which varied from 16.8 to $32.3^{\circ} \mathrm{C}$, and the humidity varied from 39 to $100 \%$. Nine multiparous and non-lactating Brown Swiss dairy cows were selected, with an average body score condition of $3.4 \pm 0.2[1-5$, in a 1 (emaciated) to 5 (obese) scale 
(Wildman et al., 1982)], at 4-8 years old and an average weight of $617.1 \pm 56.3 \mathrm{~kg}$. Only healthy animals were selected for the experiment. The diet of the cows consisted of pasture (Brachiaria decumbens), ground corn and soybean meal, minerals, and vitamins. The first SOV began after two months of supplying the diet.

\section{Superovulation and artificial insemination}

All cows received a progesterone releasing intravaginal device $\left(\mathrm{P} 4\right.$; PRIMER ${ }^{\circledR}$, Tecnopec, São Paulo, Brazil) with $3.0 \mathrm{mg}$ of estradiol benzoate (EB; RIC-BE ${ }^{\circledR}$, Tecnopec, São Paulo, Brazil) at an unknown stage in their estrous cycle (day 0). Between days 4 (day 4) and 7 (day 7), the cows were superovulated with 200 mg i.m. of pFSH (Folltropin- $V^{\circledR}$, Bioniche Animal Health, Ontario, Canada) in decreasing doses $(40,40$, $30,30,20,20,10$, and $10 \mathrm{mg}$ ) twice each day. On day 6 (day 6) and during the fifth and sixth doses of FSH treatments, all of the animals received $0.150 \mathrm{mg}$ i.m. of d-Cloprostenol (Prolise ${ }^{\circledR}$, ARSA S.R.L., Buenos Aires, Argentina). The P4 devices were removed during the last day of FSH treatment and $24 \mathrm{~h}$ after (day 8) all of the animals received $25 \mathrm{mg}$ i.m. of $\mathrm{pLH}$ (Lutropin ${ }^{\circledR}$, Bioniche Animal Health, Ontario, Canada). The experiment was conducted in a latin-square design, where each cow was superovulated three times for 27 superovulations. The minimum interval between the superovulations was two months.

According to semen type (sex-sorted or nonsorted) and the time of the AI, the cows were randomly separated into three groups, NonSx $(\mathrm{n}=9)=$ two AIs with non-sorted semen $\left(20.0 \times 10^{6}\right.$ sperm/dose $)$ conducted 12 and $24 \mathrm{~h}$ after administration of the $\mathrm{LH}$ (control group), Sx12\&24 $(\mathrm{n}=9)=$ two AIs with sexsorted semen $\left(2.0 \times 10^{6}\right.$ sperm/dose $)$ conducted 12 and 24 $\mathrm{h}$ after administration of the LH and Sx24\&36 $(\mathrm{n}=9)=$ two AIs with sex-sorted semen $\left(2.0 \times 10^{6}\right.$ sperm/dose $)$ conducted 24 and $36 \mathrm{~h}$ after administration of the LH. Figure 1 shows the protocols used for estrus synchronization and superstimulation in the Bos taurus cows that were inseminated two times according to their experimental group. The semen (sex-sorted and nonsorted) used in the experiment was obtained from the same ejaculate of one bull in the semen Central, which was previously evaluated and approved according to the minimum standard requirement.

The embryos were collected by an experienced veterinarian using standard nonsurgical uterine flushing techniques seven days after the AI. The flushing was performed using $1000 \mathrm{~mL}$ of Dulbecco's phosphatebuffered saline solution (PBS, Nutricell Nutrientes Celulares, Campinas, São Paulo, Brazil) supplemented with $1 \%$ fetal calf serum (Nutricell Nutrientes Celulares). The recovered ova/embryos were separated and evaluated according to the IETS manual (Robertson and Nelson, 1998) as grade 1 (excellent or good), 2 (fair), or 3 (poor). Grade 1 and 2 embryos were considered transferable. After the embryo collection, the numbers of corpus luteum were observed using the transrectal ultrasound technique (Falcon Vet ${ }^{\circledR}$ 100, Pie Medical, Maastricht, Holanda) with a $6.0 \mathrm{MHz}$ linear transducer.

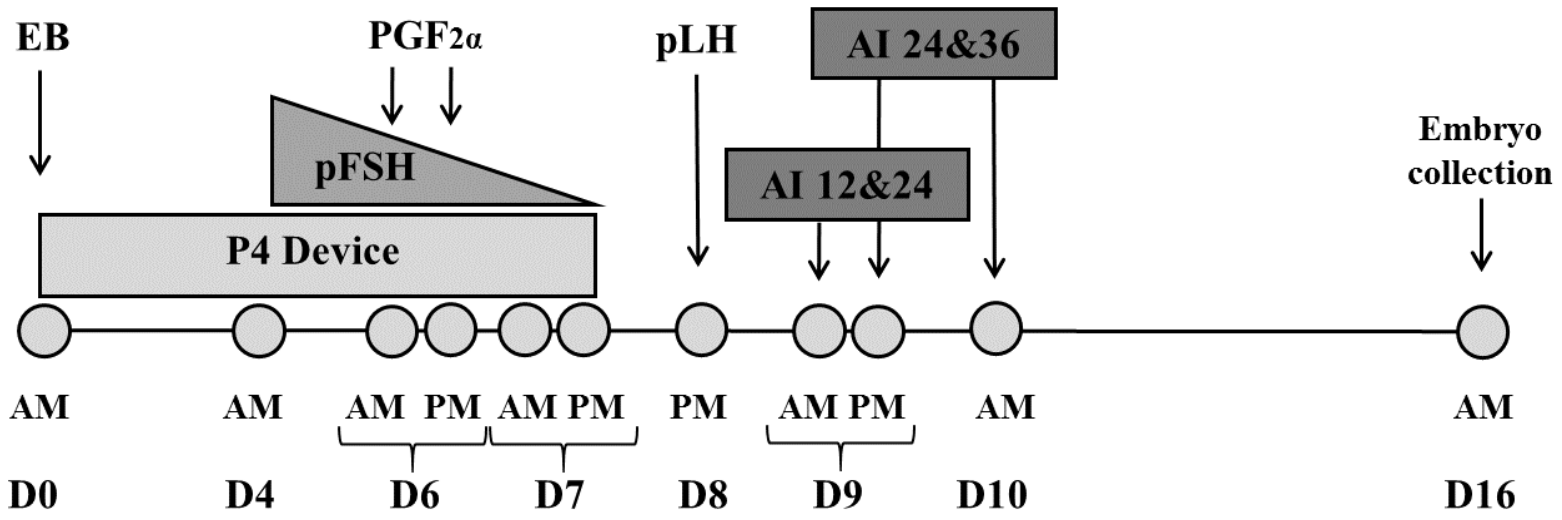

Figure 1. Treatment protocols for synchronization and superstimulation in Bos taurus cows that were inseminated two times according to their experimental group. AM - 6:00 AM; PM - 6:00 PM; P4 - Progesterone; EB - Estradiol benzoate at a dose of $3 \mathrm{mg}$; PGF2 $\alpha$ - Prostaglandin F2 $\alpha$; pFSH was administered between day 4 and day 7 twice each day; NonSx and Sx12\&24 - AI day 9 morning and afternoon; Sx24\&36 - AI day 9 in the afternoon and day 10 in the morning.

\section{Statistical analysis}

The data were analyzed using the Glimmix procedure in SAS (System for windows, Version 9.3; SAS Institute Inc., Cary, NC, USA). The model included the fixed effects of treatment and the random effect of latin-square. Orthogonal comparisons were used to determine the effects of semen type (NonSx vs. $\mathrm{Sx} 12 \& 24+\mathrm{Sx} 24 \& 36)$ and the effects of AI time (Sx12\&24 vs. Sx24\&36). Differences of $\mathrm{P} \leq 0.05$ were considered significant and differences of $0.05<\mathrm{P} \leq 0.10$ were considered tendencies. Data are shown as the least square mean \pm standard error. The cows that did not respond to superovulation or did not have embryo/ova recovered were excluded from the statistical analyses.

\section{Results}

Of the 27 performed superovulations, five cows did not produce compatible ova/embryos following the ovarian superstimulatory response, one from the NonSx group and four from the Sx24\&36 
group. From the five superovulations that did not have a stimulatory response, two were from a donor that only showed responses in the Sx12\&24 group.

There were no differences in the numbers of corpus luteum and the recovered structures number/flushing. In addition, the proportion of fertilized embryos was also similar among the treatments. However, the proportion of fertilized tended $(\mathrm{P}=0.09)$ to increase in the non-sorted semen relative to the sorted semen. No effects of semen type on the transferable embryo were observed, but the Sx24\&36 group generally $(\mathrm{P}=0.09)$ had more transferable embryos than the Sx12\&24 group. The number of degenerated embryos per flush tended $(\mathrm{P}=0.08)$ to be greater for the nonsorted semen than sex-sorted semen. A treatment effect $(\mathrm{P}=0.05)$ was observed for the proportion of degenerated embryos, where the NonSx had greater numbers compared to the Sx12\&24 and Sx24\&36 groups. The number of unfertilized oocytes per flush was smaller $(\mathrm{P}=0.05)$ when the non-sorted semen was used rather than the sorted semen. The proportion of cows with unfertilized ova was smaller for the NonSx group than for the Sx12\&24 and Sx24\&36 groups (Table 1).

No difference was observed when evaluating the proportions of cows with more than $50 \%$ of fertilized embryos per flush (Table 1).

Table 1. Results (least square mean $\pm \mathrm{SE}$ ) from superovulated cows inseminated with nonsorted and sex-sorted semensorted sperm.

\begin{tabular}{|c|c|c|c|c|c|c|}
\hline & \multicolumn{3}{|c|}{ Treatments $^{1}$} & \multicolumn{3}{|c|}{ P-value ${ }^{2}$} \\
\hline & $\begin{array}{l}\text { NonSx } \\
(\mathrm{n}=8)\end{array}$ & $\begin{array}{c}\text { Sx12\&24 } \\
(\mathrm{n}=9)\end{array}$ & $\begin{array}{c}\mathrm{Sx} 24 \& 36 \\
(\mathrm{n}=5)\end{array}$ & TRT & $\begin{array}{c}\text { Semen } \\
\text { type }\end{array}$ & $\begin{array}{c}\text { AI } \\
\text { Time }\end{array}$ \\
\hline Corpus luteum number per $\operatorname{cows}^{3}$ (n) & $11.7 \pm 1.27$ & $11.2 \pm 1.20$ & $11.7 \pm 1.59$ & 0.94 & 0.85 & 0.81 \\
\hline Embryo/oocyte per flush (n) & $8.4 \pm 2.53$ & $10.0 \pm 2.40$ & $9.4 \pm 3.16$ & 0.87 & 0.65 & 0.87 \\
\hline Fertilized per flush(n) & $5.4 \pm 1.90$ & $1.0 \pm 1.79$ & $3.8 \pm 2.40$ & 0.28 & 0.24 & 0.37 \\
\hline Fertilized per flush (\%) & $47.3 \pm 12.00$ & $15.1 \pm 11.27$ & $22.6 \pm 15.12$ & 0.18 & 0.09 & 0.70 \\
\hline Transferable embryo per flush (n) & $0.3 \pm 0.72$ & $0.3 \pm 0.68$ & $2.4 \pm 0.91$ & 0.17 & 0.25 & 0.09 \\
\hline Transferable embryo per flush (\%) & $9.8 \pm 4.50$ & $4.7 \pm 4.22$ & $16.0 \pm 5.72$ & 0.32 & 0.93 & 0.15 \\
\hline Degenerate embryo per flush (n) & $4.6 \pm 1.48$ & $0.7 \pm 1.40$ & $1.4 \pm 1.88$ & 0.18 & 0.08 & 0.76 \\
\hline Degenerate embryo per flush (\%) & $39.5 \pm 9.00^{*}$ & $10.4 \pm 8.44^{* *}$ & $2.6 \pm 11.43^{* *}$ & 0.05 & 0.01 & 0.59 \\
\hline Unfertilized oocytes per flush (n) & $3.0 \pm 1.90$ & $9.0 \pm 1.80$ & $5.7 \pm 2.35$ & 0.06 & 0.05 & 0.23 \\
\hline Unfertilized oocytes per flush (\%) & $52.8 \pm 11.95$ & $84.9 \pm 11.27$ & $77.4 \pm 15.12$ & 0.18 & 0.09 & 0.70 \\
\hline $\begin{array}{l}\text { Cows with more than } 50 \% \text { of } \\
\text { fertilized structures }{ }^{4}(\%)\end{array}$ & $50.0 \pm 16.40$ & $11.1 \pm 15.46$ & $40.0 \pm 20.75$ & 0.25 & 0.27 & 0.28 \\
\hline
\end{tabular}

${ }^{*, * *}$ Values within the same row differ TRT $\left.₫ \mathrm{P} \quad 0.05\right) .{ }^{1}$ NonSx $=$ two AI with non-sorted semen $\left(20.0 \times 10^{6}\right.$ sperms/dose) 12 and $24 \mathrm{~h}$ after administering the LH (control group); Sx12\&24 = two AI with sex-sorted semen $\left(2.0 \times 10^{6}\right.$ sperms/dose), 12 and $24 \mathrm{~h}$ after administering the LH; Sx24\&36 = two AI with sex-sorted semen $\left(2.0 \times 10^{6}\right.$ sperms/dose) performed 24 and $36 \mathrm{~h}$ after administering the LH. ${ }^{2}$ TRT $=$ effects of treatment; Semen type $=$ orthogonal comparison for the effects of semen type (NonSx vs. Sx12\&24 + Sx24\&36); AI Time = orthogonal comparison for the AI time with sexed semen. ${ }^{3}$ Only the cows that responded to the superovulation protocol. ${ }^{4}$ Proportion of the cows that showed more than $50 \%$ of fertilized structures.

\section{Discussion}

The use of sex-sorted semen in embryo production by SOV is an important tool for genetic improvement in dairy farms, consequently increasing milk production. This research evaluated the use of sexed semen in the in vivo embryo production during modifications at the time of artificial insemination. Our hypothesis that a delay at TAI using sex-sorted semen on the donors of embryo would increase the fertilization rate was rejected since the delay at the artificial insemination had no effect on the fertilization rate. The superovulatory response observed in this study showed that $18.51 \%(5 / 27)$ of the cows did not respond to the protocol that was used, which can be attributed to the variability of the female stimulatory treatments (Bo et al., 2006). The mean number of structures recovered per flush was similar to those reported in heifers (Sartori et al., 2004; Peippo et al., 2009) and Holstein cows (Peippo et al., 2009).

Although the sperm sex-sorting process has significantly evolved, when it is used in superovulated cows the fertilization rate is lower than when using nonsorted semen (Sartori et al., 2004; Larson et al., 2007,
2010; Soares et al., 2011; Kaimio et al., 2013). This result can be explained by the low sperm concentration and damage caused by the sorting process followed by freezing (dilution, laser exposure, process speed and centrifugation) (Schenk et al., 1999). In this study, the percentage of fertilized embryos per flush tended to be smaller when the sex-sorted semen was used rather than the non-sorted semen. Similar results have been reported previously (Kaimio et al., 2013). These results were observed even when greater sperm concentrations $\left(10 \times 10^{6}\right.$ and $\left.20 \times 10^{6}\right)$ were used in heat detection AI (Sartori et al., 2004), when timed AI (TAI) was used in heifers that were superovulated without an ovulation inductor (Schenk et al., 2006), when AI was conducted $6 \mathrm{~h}$ after the pre-established time (Soares et al., 2011), and when four inseminations were done with estrus observation (Larson et al., 2010).

Although no statistical differences were observed in the proportion of fertilized embryos when sex-sorted semen was used at different AI times, the number of transferable embryo per flush generally increased when the TAI was performed 24 and $36 \mathrm{~h}$ after LH administration when compared to 12 and $24 \mathrm{~h}$. In a similar study (Soares et al., 2011), it was realized 
that the use of TAI with sex-sorted semen in superovulated Bos taurus and Bos indicus cows resulted in good fertilization rates. In this case, the greatest numbers of freezable embryos were obtained when the inseminations were performed 18 and $30 \mathrm{~h}$ after LH administration, which corresponds to the findings of this study. Moreover, these results support the hypothesis that TAI with sex-sorted semen in superovulated cows should be performed during the period of greater ovulation occurrence to increase the fertilization rate.

Dalton et al. (2000) reported lower fertilization rates in superovulated cows when the AI was performed 0 or $12 \mathrm{~h}$ after the onset of estrus than when inseminated $24 \mathrm{~h}$ after $(29.0,60.0$, and $81.0 \%$, respectively). One possible explanation for failure in fertilization in superovulated cows seems to be the absence of viable sperm in the fertilization site (Schenk et al., 2006). After the AI period, possibly many sperm were removed from the female genital tract through retrograde loss and the loss of functional sperm reservoirs over the time span required for ovulation to occur (Dalton et al., 2000). The same effect can also be observed in single ovulation cows because higher pregnancy/AI is obtained when the interval between AI and ovulation is less than 16 hours when compared to intervals of $16-32 \mathrm{~h}$ and $32-48 \mathrm{~h}(50.8,28.7$, and 14.3\%, respectively; Hockey et al., 2010).

Therefore, a lower number of transferable embryos were observed when the TAI of sex-sorted semen was performed 12 and $24 \mathrm{~h}$ after $\mathrm{LH}$ administration. This result can be attributed to two causes, 1) the reduction and/or absence of suitable sperm on the fertilization site at the time of ovulation and 2) the damage that sperm cells undergo during the sexing process, which determines the loss of some sperm functions, including motility, progressive motility and the number of cells with intact plasma and acrosomal membranes (Carvalho et al., 2010).

The unavailability of sex-sorted semen from another Brown-Swiss bull used in this study led us to focus on one individual bull. As individual variations occur between bulls in the same breed (Cochran et al., 2013), it is also known that the tolerance of bovine sperm to the sexing process by flow cytometry is variable (Alomar et al., 2008; DeJarnette et al., 2008; Garner, 2009) and requires a selection of individuals that have better AI results for non-sorted semen with low sperm concentrations.

In the present study, an increase in the number of degenerated embryos occurred in the NonSx group. This finding most likely resulted from the greater number of embryos produced in this group. However, the main hypothesis that explains these results involves heat stress. Unfortunately, the donors were exposed to adverse weather conditions $\left(32.3^{\circ} \mathrm{C}\right.$ temperature and $100 \%$ humidity) during the study period. Heat stress on dairy cattle can increase the number of degenerate embryos (Putney et al., 1989) and decrease the number of fertilized and freezable structures (Vieira et al., 2014). Lower fertilization rates occur because the heat stress effect compromises the oocyte quality and alters embryonic development (Edwards et al., 2009).
Although the amount of degenerated embryos potentially compromised the clarity of the data that were obtained in this study, the results suggest a path so that we can achieve better results in the superovulated dairy cows when using the sex-sorted semen.

In conclusion, these results demonstrate that the use of sex-sorted semen in superovulated dairy cows that were raised in tropical climate results in greater numbers of unfertilized oocytes than non-sorted semen. However, when only sorted semen is used, AI should be performed 24 and $36 \mathrm{~h}$ after administering the $\mathrm{LH}$ to obtain a greater number of transferable embryos.

\section{Acknowledgments}

To Mr. Jose Maria Andrade, for providing the physical structure and financial development of the experiment; to Dr. Isabel Souza, for staff and business support through Tecnopec for the research development; and Pernambuco Research Foundation (Fundação de Amparo a Ciência e Tecnologia do Estado de Pernambuco - FACEPE) for the grant of a master scholarship to the first author.

\section{References}

Alomar M, Tasiaux H, Remacle S, George F, Paul D, Donnay I. 2008. Kinetics of fertilization and development, and sex ratio of bovine embryos produced using the semen of different bulls. Anim Reprod Sci, 107:48-61.

Bo GA, Baruselli PS, Chesta PM, Martins CM. 2006. The timing of ovulation and insemination schedules in superstimulated cattle. Theriogenology, 65:89-101.

Bo GA, Mapletoft RJ. 2014. Historical perspectives and recent research on superovulation in cattle. Theriogenology, 81:38-48.

Carvalho JO, Sartori R, Machado GM, Mourao GB, Dode MAN. 2010. Quality assessment of bovine cryopreserved sperm after sexing by flow cytometry and their use in in vitro embryo production. Theriogenology, 74:1521-1530

Chesta P, Maraña D, Peres L, Bó GA. 2005. Effect of time of removal of a progesterone releasing device and gnrh treatment on the interval to and distribution of ovulations in superstimulated beef cows. Reprod Fertil Dev, 18:288-288

Cochran SD, Cole JB, Null DJ, Hansen PJ. 2013. Single nucleotide polymorphisms in candidate genes associated with fertilizing ability of sperm and subsequent embryonic development in cattle. Biol Reprod, 89:1-7.

Dalton JC, Nadir S, Bame JH, Noftsiner M, Saacke RG. 2000. The effect of time of artificial insemination on fertilization status and embryo quality in superovulated cows. J Anim Sci, 78:2081-2085.

DeJarnette JM, Nebel RL, Marshall CE, Moreno JF, McCleary CR, Lenz RW. 2008. Effect of sex-sorted sperm dosage on conception rates in Holstein heifers and lactating cows. J Dairy Sci, 91:1778-1785.

Edwards JL, Bogart AN, Rispoli LA, Saxton AM, Schrick FN. 2009. Developmental competence of 
bovine embryos from heat-stressed ova. $J$ Dairy Sci, 92:563-570.

Garner DL. 2006. Flow cytometric sexing of mammalian sperm. Theriogenology, 65:943-957.

Garner DL. 2009. Hoechst 33342: the dye that enabled differentiation of living $\mathrm{X}$-and Y-chromosome bearing mammalian sperm. Theriogenology, 71:11-21.

Hamano K. 2007. Sex preselection in bovine by separation of $\mathrm{X}$ - and $\mathrm{Y}$-chromosome bearing spermatozoa. J Reprod Dev, 53:27-38.

Hayakawa H, Hirai T, Takimoto A, Ideta A, Aoyagi Y. 2009. Superovulation and embryo transfer in Holstein cattle using sexed sperm. Theriogenology, 71:68-73.

Hockey CD, Morton JM, Norman ST, McGowan MR. 2010. Improved prediction of ovulation time may increase pregnancy rates to artificial insemination in lactating dairy cattle. Reprod Domest Anim, 45:239-248. Kaimio I, Mikkola M, Lindeberg H, Heikkinen J, Hasler JF, Taponen J. 2013. Embryo production with sex-sorted semen in superovulated dairy heifers and cows. Theriogenology, 80:950-954.

Karakaya E, Yilmazbas-Mecitoglu G, Keskin A, Alkan A, Tasdemir U, Santos JEP, Gumen A. 2014. Fertility in dairy cows after artificial insemination using sex-sorted sperm or conventional semen. Reprod Domest Anim, 49:333-337.

Larson SF, Butler WR, Currie WB. 2007. Pregnancy rates in lactating dairy cattle following supplementation of progesterone after artificial insemination. Anim Reprod Sci, 102: 172-179.

Larson JE, Lamb GC, Funnell BJ, Bird S, Martins A, Rodgers JC. 2010. Embryo production in superovulated Angus cows inseminated four times with sexed-sorted or conventional, frozen-thawed semen. Theriogenology, 73:698-703.

Martins CM. 2007. Diferentes protocolos de superovulação com inseminação artificial em tempo fixo em Bos taurus e Bos indicus. $2007.115 \mathrm{f}$ Dissertação (mestrado) - Universidade de São Paulo, São Paulo, SP, 2007.

Nogueira MFG, Barros BJP, Teixeira AB, Trinca LA, D'Occhio MJ, Barros CM. 2002. Embryo recovery and pregnancy rates after the delay of ovulation and fixed time insemination in superstimulated beef cows. Theriogenology, 57:1625-1634.

Peippo J, Vartia K, Kananen-Anttila K, Raty M, Korhonen K, Hurme T, Myllymaki H, Sairanen A, Maki-Tanila A. 2009. Embryo production from superovulated Holstein-Friesian dairy heifers and cows after insemination with frozen-thawed sex-sorted X spermatozoa or unsorted semen. Anim Reprod Sci, 111:80-92.

Putney DJ, Mullins S, Thatcher WW, Drost M, Gross TS. 1989. Embryonic-development in superovulated dairy-cattle exposed to elevated ambienttemperatures between the onset of estrus and insemination. Anim Reprod Sci, 19:37-51.

Robertson I, Nelson RE. 1998. Certification and identification of the embryo. In: Stringfellow DA, Seidel SM (Ed.). Manual of the International Embryo Transfer Society. Savoy, Ill: International Embryo Transfer Society. pp. 103-116.

Sartori R, Souza AH, Guenther JN, Caraviello DZ, Geiger LN, Schenk JL, Wiltbank MC. 2004. Fertilization rate and embryo quality in superovulated Holstein heifers artificially inseminated with X-sorted or unsorted sperm. Anim Reprod, 1:86-90.

Schenk JL, Suh TK, Cran DG, Seidel GE. 1999. Cryopreservation of flow-sorted bovine spermatozoa. Theriogenology, 52:1375-1391.

Schenk JL, Suh TK, Seidel GE. 2006. Embryo production from superovulated cattle following insemination of sexed sperm. Theriogenology, 65:299307.

Seidel GE, Johnson LA. 1999. Sexing mammalian sperm - Overview. Theriogenology, 52:1267-1272.

Seidel GE, Schenk JL. 2008. Pregnancy rates in cattle with cryopreserved sexed sperm: effects of sperm numbers per inseminate and site of sperm deposition. Anim Reprod Sci, 105:129-138.

Soares JG, Martins CM, Carvalho NAT, Nicacio AC, Abreu-Silva AL, Campos Filho EP, Torres Junior JRS, Sa Filho MF, Baruselli PS. 2011. Timing of insemination using sex-sorted sperm in embryo production with Bos indicus and Bos taurus superovulated donors. Anim Reprod Sci, 127:148-153.

Viana JHM, Camargo LSA. 2007. A produção de embriões bovinos no Brasil: uma nova realidade. Acta Sci Vet, 35:915-924.

Vieira LM, Rodrigues CA, Mendanha MF, Sa MF, Sales JNS, Souza AH, Santos JEP, Baruselli PS. 2014. Donor category and seasonal climate associated with embryo production and survival in multiple ovulation and embryo transfer programs in Holstein cattle. Theriogenology, 82:204-212.

Wildman EE, Jones GM, Wagner PE, Boman RL, Troutt HF, Lesch TN. 1982. A dairy-cow body condition scoring system and its relationship to selected production characteristics. J Dairy Sci, 65:495-501. 